\title{
CLINICOPATHOLOGICAL STUDY OF PERFORATION PERITONITIS IN PAEDIATRIC AGE GROUP IN MY HOSPITAL, INDORE- A PROSPECTIVE AND RETROSPECTIVE STUDY
}

\author{
Sunil Narang1, Sumit Shukla², Pradeep Shivsharan ${ }^{3}$ \\ 1 Deputy Superintendent, Department of General Surgery, MGM Medical College and MYH Hospital, Indore, Madhya Pradesh. \\ 2Professor, Department of General Surgery, MGM Medical College and MYH Hospital, Indore, Madhya Pradesh. \\ ${ }^{3}$ Resident, Department of General Surgery, MGM Medical College and MYH Hospital, Indore, Madhya Pradesh.
}

\section{ABSTRACT}

\section{BACKGROUND}

In acute abdomen, the difference between the best and worst surgery is infinitely less than between early and late surgery and the greatest sacrifice of all is sacrifice of time. The aim of the present work is to find out the epidemiology of the gastrointestinal perforation in children and incidence of aetiology in such perforations and the result of different surgical procedure and management performed.

\section{MATERIALS AND METHODS}

A prospective and retrospective study was conducted in Mahatma Gandhi Memorial Medical College and MY Hospital over a period of 5 years from Jan. 2013 to Oct. 2017. A total of 106 patients presented in this period with hollow viscus perforation and out of these 59 patients were retrospective and 47 were prospective. In our study, the main diagnostic tools were history, clinical examination, scout film abdomen and operative findings. The different GI perforations were labelled under the aetiologies as enteric, idiopathic, unknown, appendicular, tubercular and miscellaneous perforation.

\section{RESULTS}

A total of 106 patients with gastrointestinal perforation were included in the study. The causes for perforation were traumatic (19.23\%), idiopathic (15.38\%) and enteric (15.38\%).

\section{CONCLUSION}

The common pathology of gastrointestinal perforation is traumatic, idiopathic and enteric fever. N. mortality is $29 \%$. Hence, the need of the day is correct recognition at the earliest opportunity of the case of perforation peritonitis, an extensive medical management and timely judgement for surgical intervention.

\section{KEY WORDS}

Gastrointestinal Perforation, Aetiology, Surgical Intervention.

HOW TO CITE THIS ARTICLE: Narang S, Shukla S, Shivsharan P. Clinicopathological study of perforation peritonitis in paediatric age group in MY Hospital, Indore- a prospective and retrospective study. J. Evolution Med. Dent. Sci. 2018;7(19):2393-2397, DOI: $10.14260 /$ jemds/2018/539

\section{BACKGROUND}

Perforation peritonitis ${ }^{1,2,3,4}$ continues to be a significant health problem. It represents a major cause of morbidity and mortality, prolonged hospitalisation and health care problem. Perforation of gastrointestinal tract of the newborn child was first reported by Siebold in 1920. Such perforations are labelled as spontaneous perforation peritonitis. The diagnosis of perforation peritonitis in some way is difficult than adults. In a history taken is plain and unembroidered. There are still many features of genesis and natural history of perforation peritonitis that are incompletely understood. Cases of perforation peritonitis have very high mortality- about $40 \%$ and more so if treated conservatively. The high mortality 20 and morbidity rates can be attributed to delay in seeking medical attention, failure by clinician to diagnose the disease early and accurately, insufficient pre-operative resuscitation and poor management.

'Financial or Other Competing Interest': None.

Submission 11-04-2018, Peer Review 23-04-2018,

Acceptance 26-04-2018, Published 07-05-2018.

Corresponding Author:

Dr. Pradeep Shivsharan,

MGM Medical College and

MYH Hospital, Indore, Madhya Pradesh.

E-mail: chill28486@gmail.com

DOI: $10.14260 /$ jemds $/ 2018 / 539$
Hence, the need of the day is correct recognition at the earliest opportunity of the cases of perforation peritonitis, an intensive medical management and timely judgement for surgical intervention. Unfortunately, it is not easy and the attending surgeon finds himself in a dilemma and the diagnosis depends upon help from detailed history, clinical, laboratory and skiagraphic examination and their interpretation. Taking into consideration the importance of this subject and its associated complications, present study has been undertaken.

\section{Aims and Objectives}

1. Study of incidence and cause of perforation peritonitis in children.

2. To evaluate the results of various lines of treatment in perforation peritonitis in children.

3. To observe the clinical presentation of perforation peritonitis and their significance as an aid to diagnosis.

4. To find out the value of laboratory, radiographic and additional diagnostic procedures as an aid to diagnosis.

\section{MATERIALS AND METHODS}

The study is being conducted in MGM Medical College and MY Hospital, Indore as a prospective and retrospective study. Patients between 0 - 12 years of age are included in the study. 
Study Design- Descriptive study.

\section{Methods}

For Retrospective Study- The old case files were taken from the Department of Surgery, MY Hospital, Indore from Jan. 2013 to Dec. 2015.

\section{For Prospective Study}

The records of admitted patients are taken from Jan. 2016 to Oct. 2017, paediatric surgery ward with gastrointestinal perforations examined, investigated and managed the following manner-

1. Particulars of the patient.

2. Recording of present complaints.

3. Past history in relation to fever, loss of weight, bowel habits, loose motions, worm infestation, any previous operation.

4. General examination of the patient to detect any signs of dehydration; a record of pulse, BP, respiration and temperature.

5. Systemic examination of the chest to rule out pneumonia or any other associated condition of lungs and heart.

6. Local examination of abdomen regarding distension, external injury, tenderness, guarding, rigidity, lump, fluid thrill, obliterated liver dullness and bowel sounds.

7. Rectal examination.

8. Investigations.

- Routine examination of urine and blood.

- Radiological examination- X-ray chest (PA view), scout film of abdomen.

- Widal test.

- Abdominal paracentesis.

- Histopathological examination of the biopsy material taken from the resected part of the bowel, mesenteric nodes, omentum etc.

After confirmation of the diagnosis treatment is either conservative or operative if operative details of surgical procedures, follow-up of treated patients, records of complications, final outcome and comments.

\begin{tabular}{|c|c|c|c|c|c|c|c|c|}
\hline Year & TRA & I/V & APP & ENTE & TB & UNK & MI & Total \\
\hline 2013 & 6 & 4 & 1 & 2 & 2 & 2 & 0 & 17 \\
\hline 2014 & 9 & 1 & 4 & 3 & 3 & 1 & 0 & 21 \\
\hline 2015 & 7 & 3 & 0 & 2 & 3 & 3 & 3 & 21 \\
\hline Total & $\mathbf{2 2}$ & $\mathbf{8}$ & $\mathbf{5}$ & $\mathbf{7}$ & $\mathbf{8}$ & $\mathbf{6}$ & $\mathbf{3}$ & $\mathbf{5 9}$ \\
\hline
\end{tabular}

Table 1. Distribution of Cases of GI Perforation of Various Aetiology, Retrospective Study

\begin{tabular}{|c|c|c|c|c|c|c|c|c|}
\hline Year & TRA & I/V & APP & ENTE & TB & UNK & MI & Total \\
\hline 2016 & 5 & 4 & 2 & 4 & 3 & 4 & 4 & 26 \\
\hline 2017 & 7 & 2 & 4 & 5 & 1 & 1 & 1 & 21 \\
\hline Total & $\mathbf{1 2}$ & $\mathbf{6}$ & $\mathbf{6}$ & $\mathbf{9}$ & $\mathbf{4}$ & $\mathbf{5}$ & $\mathbf{5}$ & $\mathbf{4 7}$ \\
\hline \multicolumn{10}{|c|}{ Prospective Study } \\
\hline
\end{tabular}

TRA- trauma, I/V- idiopathic virus, APP- appendicular, ENTE- Enteric, TB- Tuberculosis, UNK- Unknown, MISMiscellaneous. Maximum cases 26 GI Perforation in infants and children occurred in 2016. According to E/O 19.23\% TRA, $15.38 \%$ are I/V, ENT, UNK and Misc., 11.53\% TB and $7.69 \%$ APP recorded in this year.

\begin{tabular}{|c|c|c|c|c|c|c|c|c|}
\hline Age & TRA & I/V & APP & ENTE & TB & UNK & MIS & Tota \\
\hline 1D & - & 1 & - & - & - & 1 & - & 2 \\
\hline $1 \mathrm{M}$ & - & - & - & - & - & 2 & - & 2 \\
\hline $1 Y$ & - & 1 & - & - & - & 2 & - & 3 \\
\hline $2 Y$ & - & 1 & - & - & - & 1 & - & 2 \\
\hline $3 Y$ & 1 & - & - & - & - & 2 & - & 3 \\
\hline $4 Y$ & 1 & - & - & - & 1 & 2 & - & 4 \\
\hline $5 Y$ & 2 & - & - & 1 & 2 & 1 & 1 & 7 \\
\hline $6 \mathrm{Y}$ & 4 & - & - & 3 & - & - & - & 7 \\
\hline $7 Y$ & 1 & - & - & 1 & - & - & - & 2 \\
\hline $8 \mathrm{Y}$ & 2 & - & - & - & 2 & - & 1 & 5 \\
\hline $9 \mathrm{Y}$ & 1 & - & - & - & 1 & - & - & 2 \\
\hline $10 \mathrm{Y}$ & 2 & - & 1 & 1 & 1 & - & - & 5 \\
\hline $11 \mathrm{Y}$ & 2 & - & - & 1 & 1 & 1 & - & 5 \\
\hline $12 \mathrm{Y}$ & 6 & - & 4 & - & - & - & - & 10 \\
\hline Total & 22 & 3 & 5 & 7 & 8 & 12 & 2 & 59 \\
\hline \multicolumn{9}{|c|}{$\begin{array}{c}\text { Table 2. Depicts Aetiological Factors of Gastrointestinal } \\
\text { Perforation in Relation to different Age Group, } \\
\text { Retrospective Study }\end{array}$} \\
\hline
\end{tabular}

Maximum perforation occurred in age group 5 - 12 years taking all cases. The main aetiological factors in this age group are (traumatic5,6,7,8 46.51\%) followed by enteric ${ }^{9}$ (16.27\%), tubercular 16.27\%, appendicular (11.62\%), unknown $4.65 \%$.

\begin{tabular}{|c|c|c|c|c|c|c|c|c|}
\hline Age & TRA & I/V & APP & ENTE & TB10 & UNK & MIS11 & Total \\
\hline 1D & - & - & - & - & - & 1 & - & 1 \\
\hline $1 \mathrm{M}$ & - & 4 & - & - & - & 4 & 4 & 12 \\
\hline $1 Y$ & - & 2 & 1 & - & - & - & - & 3 \\
\hline $2 Y$ & - & - & - & - & - & - & - & - \\
\hline $3 \mathrm{Y}$ & 1 & - & - & - & - & - & - & 1 \\
\hline $4 \mathrm{Y}$ & - & - & - & - & - & - & - & - \\
\hline $5 Y$ & 1 & - & - & - & - & - & - & 1 \\
\hline $6 Y$ & 1 & - & - & 1 & - & - & - & 2 \\
\hline $7 Y$ & 2 & - & 1 & - & 1 & - & - & 4 \\
\hline $8 Y$ & 1 & - & 2 & - & - & - & - & 3 \\
\hline $9 Y$ & - & - & - & 1 & - & - & - & 1 \\
\hline $10 \mathrm{Y}$ & 1 & - & 1 & 3 & 1 & - & 1 & 7 \\
\hline $11 \mathrm{Y}$ & 1 & - & 1 & 2 & - & - & - & 4 \\
\hline $12 \mathrm{Y}$ & 4 & - & - & 2 & 2 & - & - & 8 \\
\hline Total & 12 & 6 & 6 & 9 & 4 & 5 & 5 & 47 \\
\hline
\end{tabular}

Prospective studies show that maximum GI perforations is seen in age group of $7-12$ years including all cases. The aetiology in this age group is enteric perforation ${ }^{12,13}$ (29.62\%) followed by appendicular (18.51\%).

\begin{tabular}{|c|c|c|c|c|c|c|}
\hline $\begin{array}{c}\text { Type of } \\
\text { Perforation }\end{array}$ & $\begin{array}{c}\text { No. of } \\
\text { Cases }\end{array}$ & \multicolumn{2}{|c|}{ Male } & \multicolumn{2}{c|}{ Female } & M:F \\
\hline & & No. & $\%$ & No. & $\%$ & \\
\hline TRA & 22 & 11 & 50.0 & 11 & 50.0 & $1: 1$ \\
\hline I/V & 3 & 2 & 66.66 & 1 & 33.33 & $2: 1$ \\
\hline APP & 5 & 5 & 100.00 & - & - & - \\
\hline ENTE & 7 & 4 & 57.14 & 3 & 42.86 & $1.33: 1$ \\
\hline TB & 8 & 1 & 12.50 & 7 & 87.50 & $.142: 1$ \\
\hline UNK & 12 & 6 & 50.00 & 6 & 50.00 & $1: 1$ \\
\hline MIS & 2 & - & - & 2 & 100.00 & - \\
\hline Total & 59 & 29 & $\mathbf{4 9 . 1 5}$ & 30 & 50.85 & $0.96: 1$ \\
\hline Table 4. Sex Distribution in different Aetiologies, \\
\multicolumn{6}{|c|}{ Retrospective Study } \\
\hline
\end{tabular}




\begin{tabular}{|c|c|c|c|c|c|c|}
\hline Type of Perforation & No. of Cases & \multicolumn{2}{|c|}{ Male } & \multicolumn{2}{c|}{ Female } & M:F \\
\hline & & No & $\%$ & No & \% & $1.5: 1$ \\
\hline TRA & 12 & 8 & 66.66 & 4 & 33.33 & $1.5: 1$ \\
\hline I/V & 6 & 4 & 66.66 & 2 & 33.33 & $1: 1$ \\
\hline APP & 6 & 3 & 50.00 & 3 & 50.00 & $1.25: 1$ \\
\hline ENTE & 9 & 5 & 55.55 & 4 & 44.45 & $0.33: 1$ \\
\hline TB & 4 & 1 & 25.00 & 3 & 75.00 & $1.50: 1$ \\
\hline UNK & 5 & 3 & 60.00 & 2 & 40.00 & $4: 1$ \\
\hline MIS & 5 & 4 & 80.00 & 1 & 20.00 & $\mathbf{4 0 . 4 3}$ \\
\hline Total & $\mathbf{4 7}$ & $\mathbf{2 8}$ & $\mathbf{5 9 . 5 7}$ & $\mathbf{1 9}$ & $\mathbf{4}$ \\
\hline
\end{tabular}

Retrospective study shows female preponderance ratio and prospective study shows male preponderance ratio.

\begin{tabular}{|c|c|c|c|c|c|c|c|c|c|c|c|}
\hline Year & OES & Gastric & Jej & Ileum & App & Colon & GB & Mid Gut & Unknown & MIS & Total \\
\hline 2013 & - & - & - & 6 & 1 & 2 & - & - & 8 & - & 17 \\
\hline 2014 & - & - & - & 11 & 4 & 1 & - & - & 4 & 1 & 21 \\
\hline 2015 & - & - & - & 13 & - & 1 & - & - & 6 & 1 & 21 \\
\hline 2016 & - & - & 2 & 11 & 1 & 5 & - & - & 6 & 1 & 26 \\
\hline 2017 & - & - & - & 11 & 4 & 1 & - & - & 5 & - & 21 \\
\hline Total & - & - & $\mathbf{2}$ & $\mathbf{5 2}$ & $\mathbf{1 0}$ & $\mathbf{1 0}$ & - & - & $\mathbf{2 9}$ & $\mathbf{3}$ & $\mathbf{1 0 6}$ \\
\hline
\end{tabular}

Table 6. Annual Evidence and GI Perforations of various Sites, Retrospective and Prospective Study

\begin{tabular}{|c|c|c|c|c|c|c|c|c|}
\hline Month & TRA & I/V & APP & ENT & TB & UNK & MIS & TOTAL \\
\hline $1-3$ & 8 & 2 & 4 & 4 & 2 & 2 & 2 & 24 \\
\hline $4-6$ & 8 & 3 & 3 & 5 & 5 & 6 & 4 & 34 \\
\hline $7-9$ & 9 & 4 & 2 & 4 & 2 & 3 & 2 & 26 \\
\hline $10-12$ & 9 & 5 & 2 & 3 & 3 & 0 & 0 & 22 \\
\hline Total & $\mathbf{3 4}$ & $\mathbf{1 4}$ & $\mathbf{1 1}$ & $\mathbf{1 6}$ & $\mathbf{1 2}$ & $\mathbf{1 1}$ & $\mathbf{8}$ & $\mathbf{1 0 6}$ \\
\hline
\end{tabular}

Maximum perforation in $2^{\text {nd }}$ quarter of the year (32.07\%) in the month of April and June followed by third and $1^{\text {st }}$ quarters of year.

\begin{tabular}{|c|c|c|c|c|c|c|c|}
\hline Type & Total & Pain & Fever & Disten. & Vomit & Constit. & Diarrhoea \\
\hline TRA & 22 & 22 & 1 & 17 & 8 & 4 & - \\
\hline I/V & 8 & 1 & 2 & 8 & 8 & 6 & - \\
\hline APP & 5 & 5 & 5 & 1 & 3 & 1 & - \\
\hline ENT & 7 & 7 & 7 & 7 & 7 & 4 & - \\
\hline TB & 8 & 8 & 8 & 8 & 7 & 8 & - \\
\hline UNK & 3 & 3 & - & 3 & 1 & - & - \\
\hline MIS & 6 & 3 & 4 & 6 & 6 & 3 & - \\
\hline Total & $\mathbf{5 9}$ & $\mathbf{4 9}$ & $\mathbf{2 7}$ & $\mathbf{5 0}$ & $\mathbf{4 0}$ & $\mathbf{2 6}$ & - \\
\hline \multicolumn{8}{|l}{} \\
\hline
\end{tabular}

\begin{tabular}{|c|c|c|c|c|c|c|c|}
\hline Type & Total & Pain & Fever & Disten. & Vomit & Constit. & Diarrhoea \\
\hline TRA & 12 & 12 & - & 8 & 8 & 1 & - \\
\hline I/V & 6 & 1 & 2 & 6 & 4 & 5 & - \\
\hline APP & 6 & 6 & 3 & 6 & 6 & 6 & - \\
\hline ENT & 9 & 8 & 7 & 9 & 8 & 9 & - \\
\hline TB & 4 & 4 & 4 & 4 & 4 & 3 & - \\
\hline UNK & 5 & - & 2 & 5 & 3 & 5 & - \\
\hline MIS & 5 & 1 & 1 & 5 & 2 & 5 & - \\
\hline Total & $\mathbf{4 7}$ & $\mathbf{3 2}$ & $\mathbf{1 9}$ & $\mathbf{4 3}$ & $\mathbf{3 5}$ & $\mathbf{3 4}$ & - \\
\hline \multicolumn{2}{|l}{} \\
\hline
\end{tabular}

Abdominal distention and pain are the main complaints of patients in GI perforation (84.74\%) and (83.05\%) followed by vomiting (67.79\%), fever (45.76\%) and constipation (44.06\%) in retrospective study

In prospective study, abdominal distention and vomiting (91.48\% and $74.46 \%)$ and pain (72.34\%). In appendicular perforation, abdominal pain is the leading feature.

\begin{tabular}{|c|c|c|c|c|c|c|}
\hline Type & Total & Tend. & Rigidity & Obl Liver Dullness & \multicolumn{2}{|c|}{ Bowel Sounds } \\
\hline & & & & & \multicolumn{2}{c|}{ P } \\
\hline TRA & 22 & 22 & 10 & 3 & 15 & 7 \\
\hline I/V & 8 & 4 & 8 & 4 & - & 8 \\
\hline APP & 5 & 5 & 1 & 1 & 3 & 2 \\
\hline
\end{tabular}




\begin{tabular}{|c|c|c|c|c|c|c|}
\hline ENT & 7 & 7 & 7 & 3 & 1 & 6 \\
\hline TB & 8 & 8 & 7 & 2 & 3 & 5 \\
\hline UNK & 6 & 5 & 5 & 2 & 5 & 1 \\
\hline MIS & 3 & 3 & 3 & 1 & 2 & $\mathbf{2 5}$ \\
\hline Total & $\mathbf{5 9}$ & $\mathbf{5 4}$ & $\mathbf{4 1}$ & $\mathbf{1 6}$ & $\mathbf{3 4}$ \\
\hline \multicolumn{2}{|r|}{ Table 10. Clinical Signs in different Types of Perforation, Retrospective Study } \\
\hline
\end{tabular}

\begin{tabular}{|c|c|c|c|c|c|c|c|}
\hline \multicolumn{2}{|c|}{ Type } & \multirow[t]{2}{*}{ Total } & \multirow[t]{2}{*}{ Tend. } & \multirow[t]{2}{*}{ Rigidity } & \multicolumn{2}{|c|}{ Obl Liver Dullness } & \multirow{2}{*}{$\begin{array}{c}\text { Bowel Sounds } \\
A\end{array}$} \\
\hline & & & & & & $\mathbf{P}$ & \\
\hline TRA & 12 & 12 & & 9 & 3 & 2 & 10 \\
\hline $\mathrm{I} / \mathrm{V}$ & 6 & 1 & & 5 & - & - & 6 \\
\hline APP & 6 & 5 & & 3 & - & - & 6 \\
\hline ENT & 9 & 8 & & 8 & 3 & - & 9 \\
\hline TB & 4 & 4 & & 3 & 1 & 1 & 3 \\
\hline UNK & 5 & - & & 3 & - & - & 5 \\
\hline MIS & 5 & 1 & & 1 & - & - & 5 \\
\hline Total & 47 & 31 & & 32 & 7 & 3 & 44 \\
\hline \multicolumn{8}{|c|}{ Table 11. Prospective Study } \\
\hline
\end{tabular}

Abdominal tenderness and rigidity are the cordial sign of GI perforation (91.52\% and 65.95\%) and (69.49\%, 68.08\%).

\begin{tabular}{|c|c|c|c|}
\hline Type & Total No. of Cases in which Test Performed & Widal Positive & $\begin{array}{c}\text { Test } \\
\text { Positive \% }\end{array}$ \\
\hline Enteric & 7 & 5 & 71.42 \\
\hline Enteric & Prospective & 6 & 66.66 \\
\hline \multicolumn{2}{|c|}{ Table 12. Showing Results of Widal Test in Case of Enteric Perforation } \\
\hline
\end{tabular}

\begin{tabular}{|c|c|c|c|c|c|c|c|}
\hline $\begin{array}{c}\text { Retrospective } \\
\text { Type }\end{array}$ & $\begin{array}{c}\text { Total } \\
\text { Cases }\end{array}$ & $\begin{array}{c}\text { Simple Repair and } \\
\text { Peritoneal Drainage }\end{array}$ & Appendicectomy & $\begin{array}{c}\text { Resection and } \\
\text { Anastomosis }\end{array}$ & Other & $\begin{array}{c}\text { Conservative } \\
\text { Peritoneal } \\
\text { Drainage }\end{array}$ \\
\hline TRA & 22 & 16 & - & - & 5 & - & 1 \\
\hline I/V & 8 & 1 & - & - & - & 1 & 6 \\
\hline APP & 5 & - & 2 & -- & - & - & 3 \\
\hline ENT & 7 & 5 & - & - & - & - & 3 \\
\hline TB & 8 & 5 & - & - & - & - & 3 \\
\hline UNK & 6 & - & - & - & - & 1 & 5 \\
\hline MIS & 3 & 1 & - & - & - & - & 2 \\
\hline Total & $\mathbf{2 8}$ & - & $\mathbf{5}$ & $\mathbf{2}$ & $\mathbf{2 2}$ \\
\hline \multicolumn{7}{|l}{ Table 13. Different Modes of Treatment in different Types of GI Perforation, Retrospective Study } \\
\end{tabular}

\begin{tabular}{|c|c|c|c|c|c|c|c|}
\hline Type & Total Cases & $\begin{array}{c}\text { Simple Repair and } \\
\text { Peritoneal Drainage }\end{array}$ & Appendicectomy & $\begin{array}{c}\text { Resection and } \\
\text { Anastomosis }\end{array}$ & Other & Conservative & $\begin{array}{c}\text { Peritoneal } \\
\text { Drainage }\end{array}$ \\
\hline TRA & 12 & 11 & - & 1 & - & - & - \\
\hline I/V & 6 & 3 & - & 1 & - & - & 2 \\
\hline APP & 6 & - & 3 & - & - & - & 3 \\
\hline ENT & 9 & 6 & - & 1 & - & - & 2 \\
\hline TB & 4 & 3 & - & - & - & - & 1 \\
\hline UNK & 5 & 2 & - & - & - & 2 & 1 \\
\hline MIS & 5 & 4 & - & - & - & - & 1 \\
\hline Total & $\mathbf{4 7}$ & $\mathbf{3}$ & $\mathbf{3}$ & - & $\mathbf{2}$ & $\mathbf{1 0}$ \\
\hline \multicolumn{7}{|r|}{} \\
\hline
\end{tabular}

Retrospective study shows that operative management was the main modality of management. $47.45 \%$ cases managed by simple repair and peritoneal drainage, out of which peritoneal drainage was done in $37.28 \%$ of cases for general condition of the patient. The conservative management was undertaken in $3.38 \%$ cases.

A prospective study shows that operative management was undertaken in $70 \%$ of the cases, out of which simple repair and peritoneal drainage was done in 61.70 and $21.27 \%$ patients managed by peritoneal drainage. The conservative management was undertaken in $4.25 \%$ cases.

\section{DISCUSSION}

Perforation of Unknown Site and Aetiology

1. The aim of the present work was to find out the epidemiology of the gastrointestinal perforation in children and incidence of the aetiology in such perforation and the result of different surgical procedures and management performed at MY Hospital, Indore during 5 years.

2. Enteric Perforation

History of remittent fever $>2$ weeks, positive Widal test, usually $>1$ ileal perforation. Not any typical feature of any known aetiology.

3. Idiopathic Perforation 
Irregular fever for $<2$ weeks, single ileal perforation, negative Widal.

4. Appendicular Perforation

Perforated or gangrenous appendix with surrounding oedema.

5. Tubercular Perforation

History of pulmonary TB or gastrointestinal TB present and confirmed by HP examination of involved mesenteric LN.

6. Miscellaneous Perforations

Very rare site and incidence. There are Meckel's diverticulum, volvulus of gut, ileal atresia, vitellointestinal duct, colonic perforation etc.

\section{Traumatic Perforations}

History of blunt or penetrating trauma over abdomen.

\section{Epidemiology of Gastrointestinal Perforation in Children}

- Incidence of prevalence- $1.34 \%$ of all admissions.

- Age incidence- $58.49 \%$ in the age group of $5-12$ years.

- $23.58 \%$ in the age group of $1 \mathrm{D}-2$ years.

- Sex incidence- prospective: $\mathrm{M}: \mathrm{F}=0.96: 1$, retrospective $\mathrm{M}: \mathrm{F}=1.47: 1$

- Traumatic perforation, $\mathrm{M}: \mathrm{F}=1.26: 1$

- Appendicular 2.66: 1

- $\quad$ Enteric 1.28: 1

- Tubercular 0.2: 1

- Miscellaneous 1.33: 1

- Aetiology- Traumatic perforation $33.07 \%$

- $\quad$ Enteric perforation, $15.09 \%$

- Idiopathic perforation, $13.20 \%$

- Appendicular and unknown $10.37 \%$ each

- Miscellaneous, $7.54 \%$

- Site of perforation- usually the small gut followed by colon, duodenum, stomach are the commonest sites of perforation.

\section{CONCLUSION}

Maximum cases of GI perforation $14,15,16$ occurred in 2016 (19.31\%) irrespective of the aetiology- Traumatic $(19.23 \%)$ and Idiopathic (15.38\%) and Enteric (15.38\%) were the main aetiology. Miscellaneous and unknown site perforations (15.30\%). Age incidence was max in 5 - 12 years; however, miscellaneous group neonates and infants were under 1 year of age in retrospective study and $<12$ years of age in prospective study. Female preponderance in retrospective study (0.96:1) and male preponderance in prospective study (1.47:1). For clinical diagnosis, main symptoms were abdominal distention (84.74\%) and pain (83.05\%) and signs were generalised tenderness $(91.52 \%)$ in retrospective study and rigidity $(68.08 \%)$ in prospective study. Operative management was the main modality of treatment $(47.45 \%$ and $61.70 \%$ ). The site of perforation was ilium (49.05\%). In general, mortality rate was $29 \%$.

\section{REFERENCES}

[1] Gupta SD. Spontaneous perforation of the intestine in infancy \& childhood. New Delhi. Indian Journal of Surgery 1963;25:443-7.
[2] Ladha A. Gastrointestinal perforation. Indian Journal of Surgery 1988;50:500-8.

[3] Tripathi MD. Peritonitis - study of factors contributing to mortality. Indian Journal of Surgery 1993;55:342-9.

[4] Dandapat MC, Mukherjee LM, Mishra SB, et al. Gastrointestinal perforations. Indian Journal of Surgery 1991;53:189-93.

[5] Ogata M, Tsuganezawa 0 . An isolated perforation of the jejunum caused by child abuse. A case report. (Department of Legal Medicine, Faculty of Medicine, Kagoshima University, Japan. Am J Forensic Med Pathol 1995;16(1):17-20.

[6] Emanuel B, Zlotnik P, Reffensperger JG. Perforation of gastrointestinal tract in infancy and childhood. Surg Gynecol \& Obstet 1978;146(6):926-8.

[7] Tracy T Jr, O'Connor TP, Weber TR. Battered children with duodenal avulsion \& transection (Department of Surgery, Cardinal Glennan Children's Hospital, St Lovis). Am Surg 1993;59(6):342-5.

[8] Ceelan W, Hesse V, De Hemptime B. Small bowel perforation following blunt trauma abdomen (Surgery Department, University of Cent, Belgium). 1995:(95).

[9] Dhar A, Bagga D, Teneja SB. Perforation tubercular enteritis of childhood: a ten years study (Department of Pediatric Surgery, Lady Harding Medical College, New Delhi). Indian J of Pediatr 1990:57(5):713-6.

[10] Sandikli MU, Colakoglus, Ergun Y. Presenttation \& role of peritonioscopy in the diagnosis of tuberculosis peritonitis aand reports of gastroenterology. Cukurova University, Medical Faculty, Adama, Turkey. 1992.

[11] Dilek ON, Sekeir B, Dilek FH, et al. Performed gastric ulcer in children. Case report (Department of Surgery, University of YOZ Unc Yi School of Medicine, Van, Tykery. Acta Chir Belg 1995;95(4 Suppl):182-3.

[12] Gupta V, Gupta SK, Shukla VK, et al. Perforated typhoid enteritis in children (Department of Pediatric, Banaras Hindu University, Varanasi, India). Postgrad Med J 1994;70(819):19-22.

[13] Kurlberg G, Frisk B. Factors reducing mortality in typhoid ileal perforation (Surgical Department, Vaddevalla Hospital Sweden). Transactions of the Royal Society of Tropical Medicine and Hygiene 1991;85(6):793-5.

[14] Gosfeld JL, Molinari F, Chart M, et al. Gastrointestinal perforation and peritonitis in infants and children: experience with 179 cases over 10 years (Department of Surgery, Indiana University School of Medicine, Indiana Polis, USA). Surgery 1996:120(4):650-6.

[15] Bell MJ. Perforation of the gastrointestinal tract and peritonitis in the neonate. Surg Gynecol Obstet 1985;160(1):20-6.

[16] Tan CEL, Kiely EM, Agrawal M, et al. Neonatal gastrointestinal perforation. Journal of Pediatric Surgery 1989;24(9):888-92. 